\title{
Active power filter with hysteresis current control loop using rectifier boost technique
}

\author{
Rahimi Baharom ${ }^{1}$, Ihsan Mohd Yassin², Muhamad Nabil Hidayat ${ }^{3}$ \\ Faculty of Electrical Engineering, Universiti Teknologi MARA, Malaysia
}

\begin{tabular}{l}
\hline \hline Article Info \\
\hline Article history: \\
Received Dec 17, 2019 \\
Revised Feb 27, 2020 \\
Accepted Mar 13, 2020 \\
\hline
\end{tabular}

\section{Keywords:}

Active power filter Hysteresis current control Power factor correction Total harmonics distortion

\begin{abstract}
This paper presents the Hysteresis Current Control (HCC) to improve the power quality of power electronic converters. The development of HCC was implemented using Active Power Filter (APF) function based on rectifier boost technique to control the range of upper and lower bands. Through this technique, the supply current waveform followed the shape of the sinusoidal reference signal, thus, the distorted input current waveform becomes sinusoidal and in the same phase with the input voltage. As a result, the THD level and switching losses can be reduced, thus improving the power factor of the power supply system. In order to verify the proposed operation, validation of the proposed HCC was done through MATLAB. Selected simulation results are presented
\end{abstract}

This is an open access article under the $\underline{C C B Y-S A}$ license.

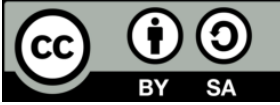

\section{Corresponding Author:}

Rahimi Baharom,

Faculty of Electrical Engineering,

Universiti Teknologi MARA,

40450 Shah Alam, Selangor, Malaysia.

Email: rahimi6579@gmail.com

\section{INTRODUCTION}

In the era of growing technology, many industries utilize power electronic applications, such as uninterruptible power supply (UPS), switch mode power supply (SMPS) and many more [1-3]. The use of power electronic converters could lead to non-sinusoidal input current which contains harmonics that are harmful to electrical devices. This, in turn, increases power quality issues, such as continuous distortion of normal voltage [4] in the power supply system.

Different methods have been suggested to solve this harmonics problem [5-7]. Among the known methods is using passive filters that are fed to the non-linear loads (NLL). This result in improvements in power factor and harmonic suppression. It also exhibits lower impedance at a tuned harmonics frequency. This method is popular due its simplicity, reliability, efficiency and low cost [8-9]. However, this method lack in current compensation, tuning and parallel resonant problems with random frequency variations.

Therefore, APF is introduced to rectify this issue. APF compensates the non-sinusoidal input current waveform of the NLL. This method solves the harmonic problem but introduces significant switching losses and reduced efficiency [10]. As a result, current control techniques such as Pulse Width Modulation technique, Delta Modulation and Hysteresis Current Control (HCC) are introduced to overcome the switching losses [11-13]. In this paper, HCC is proposed as the foundation to be implemented in the APF. 


\section{PROPOSED HYSTERESIS CURRENT CONTROL}

The HCC method has been recognized as the best approach for APF function, electrical drives and power semiconductor converters [14-19]. HCCs have a variable switching frequency under different load conditions and/or command current. The features of such technique are their capability to stabilized nonlinear load condition with a good transient response and high accuracy. Other than that, through this technique, the peak to peak value of current ripple can be controlled according to the desired hysteresis upper and lower band limits [20-24].

In this paper, HCC was implemented in the closed current control loop, as shown in Figure 1. Due to non-characteristic harmonics in the APF, HCC can control the peak-to-peak value of the ripple current in desired hysteresis band limit. To control the switching losses in the supply current, HCC was injected into the current loop of the APF by replacing the repeating sequences and the relational operators with hysteresis band limits. The hysteresis band limits control the supply current's upper band and lower bands. The supply current initially passes through the subtractor which serves as a converter which uses different overflow modes to display the output data form [25]. Next, the signal goes through the PI controller to remove the occurring error signal [26]. The main objective of HCC is to make sure the supply current follows the reference current signal. To verify the current ripple to follow the signal, step response controller is installed in the proposed design.

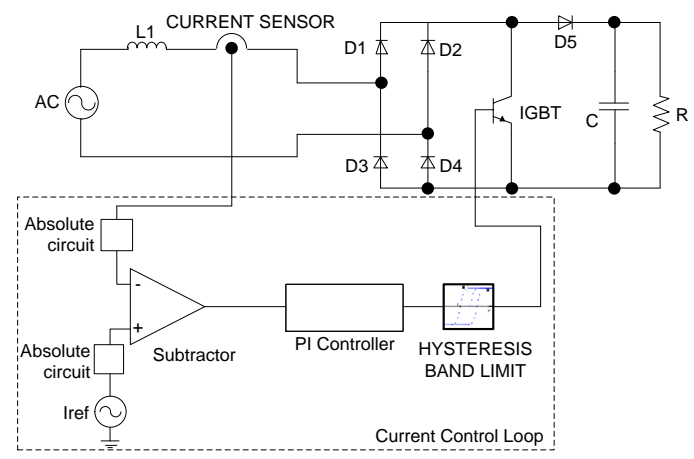

Figure 1. The proposed HCC in APF

\section{COMPUTER SIMULATION MODEL}

The circuit simulation of the proposed model began with the basic rectifier circuit without any filter. The rectifier is connected with power supply and RC load. The specification of the HCC designs is as tabulated in Table 1. Figure 2 shows the HCC model in the current loop circuit.

To verify the supply current waveform to follow the reference signal, the supply current is varied to be increase or to be reduce. The proposed configuration technique model is verified by using step response as shown in Figure 3. The use of step response in this technique is to verify that the input current will follow the shape and amplitude of desired reference signal. The modeling of step response controller is illustrated in Figure 4 by adding reference current and varying current as the input to the HCC.

Table 1. Circuit specifications

\begin{tabular}{cc}
\hline Variable & Values \\
\hline Supply voltage, $V_{s}$ & $40 \mathrm{Vrms}$ \\
Boost inductor, $L_{s}$ & $1 \mathrm{mH}$ \\
DC capacitor filter, $C_{o}$ & $1000 \mu \mathrm{F}$ \\
Load resistor, $R_{L}$ & $300 \Omega$ \\
Frequency, $f_{s}$ & $50 \mathrm{kHz}$ \\
Proportional Gain, $K_{p}$ & 80 \\
Integral gain, $K_{i}$ & 1000 \\
\hline
\end{tabular}




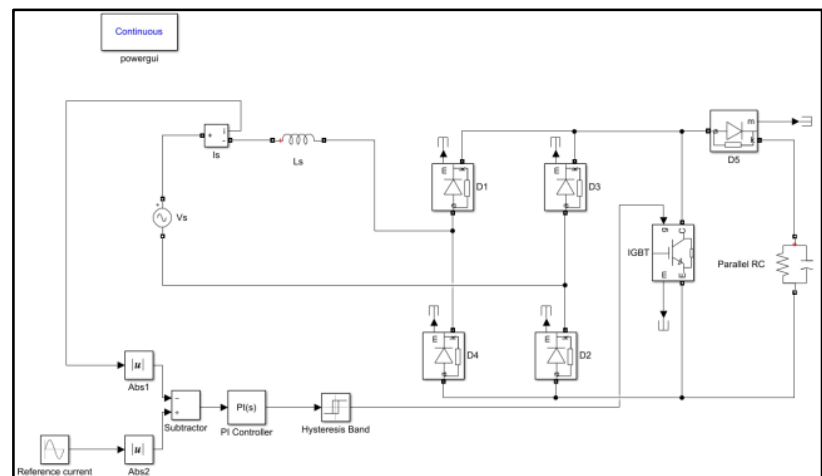

Figure 2. APF with HCC model

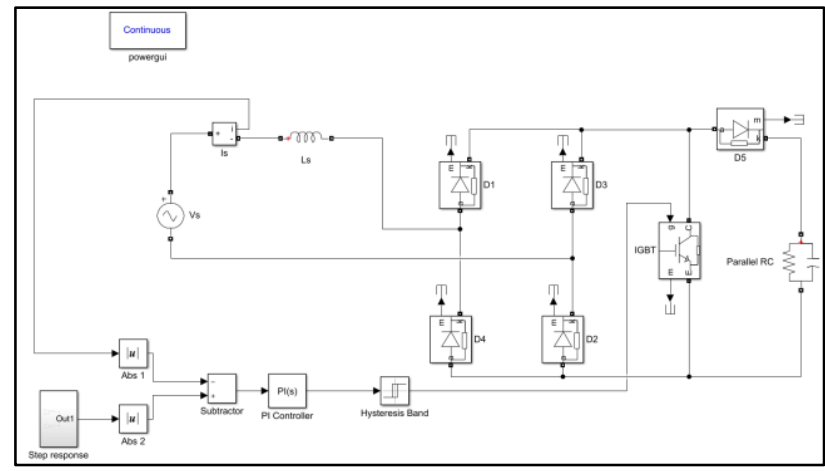

Figure 3. Step response model

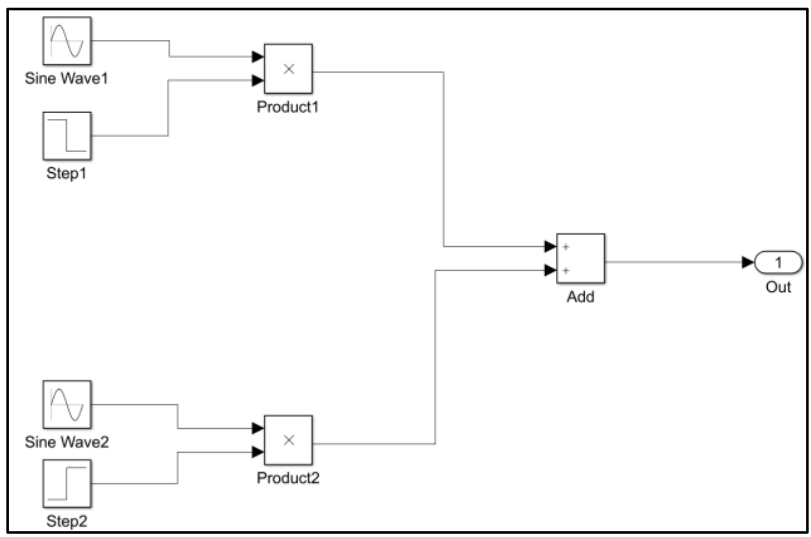

Figure 4. Step response sub-system

\section{RESULTS AND DISCUSSION}

Figure 5 shows the result of input current waveform of the converter without APF function. This state shows distortion in the supply current and consists of harmonics where the THD level are exceeding the IEEE 519 standard. With the proposed HCC in the APF function, the supply current waveform is in-phase with the supply voltage waveform shown in Figure 6. Figure 7 shows the supply current following the sinusoidal reference signal. The switching losses in the supply current are controlled by the band limit. The limit of the band affects the output of the waveform and the hysteresis band are kept within $5 \%$ from the reference current.

Table 2 shows the THD level of the input current waveform between the rectifier without filter and after applying the proposed APF with HCC. The results show that by applying HCC, the THD level can be reduce and comply with the IEEE 519 standard. Figures 8 and 9 show the step response signal representing

Active power filter with hysteresis current control loop using rectifier boost technique (Rahimi Baharom) 
step increase and decrease of the reference signal to verify that the supply current waveform keep track the shape of the reference signal with a propoer designed of current control loop.

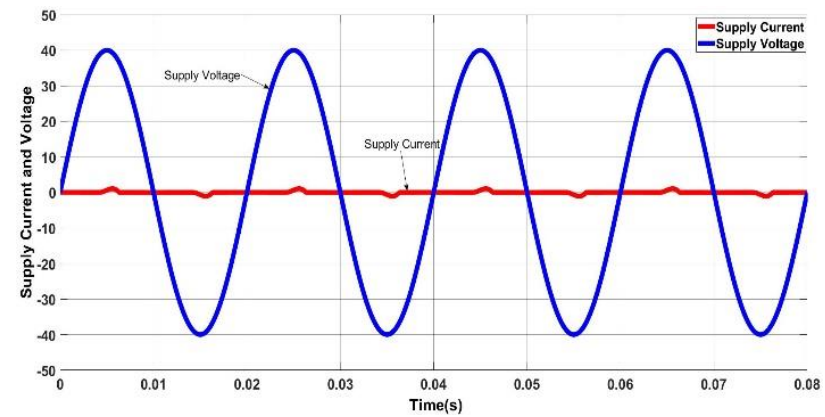

Figure 5. Non-sinusoidal input current

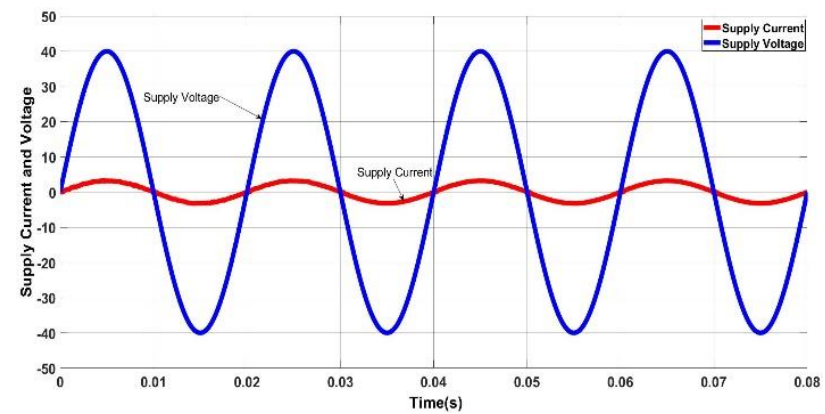

Figure 6. Sinusoidal input current in phase with the voltage waveforms

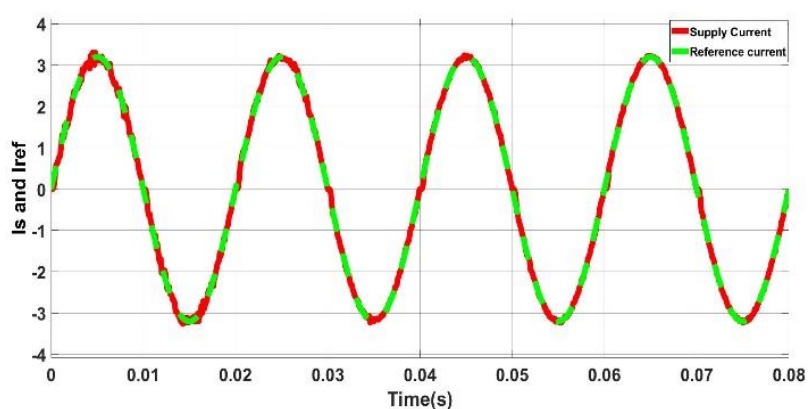

Figure 7. Input current keep track the reference signal by applying APF with HCC

Table 2. The comparison of THD level

\begin{tabular}{cc}
\hline Parameters & THD level (\%) \\
\hline No filters & 152.36 \\
APF and HCC & 3.68 \\
\hline
\end{tabular}




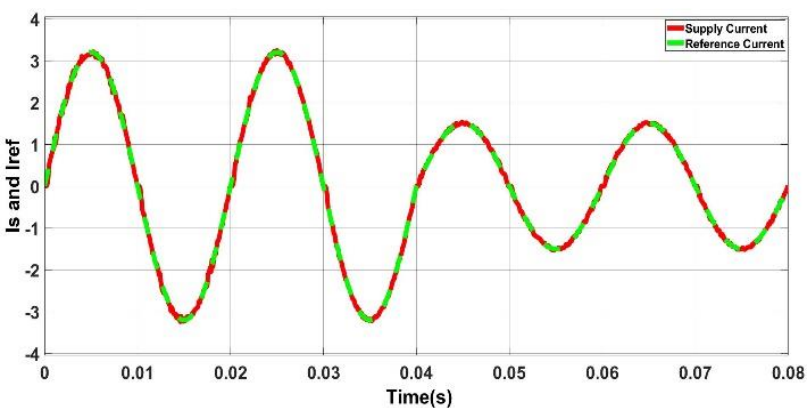

Figure 8 . The step response signal with Iref $=3.2 \mathrm{~A}$ at $0.04 \mathrm{~s}$ and Iref $=1.5 \mathrm{~A}$ at $0.08 \mathrm{~s}$

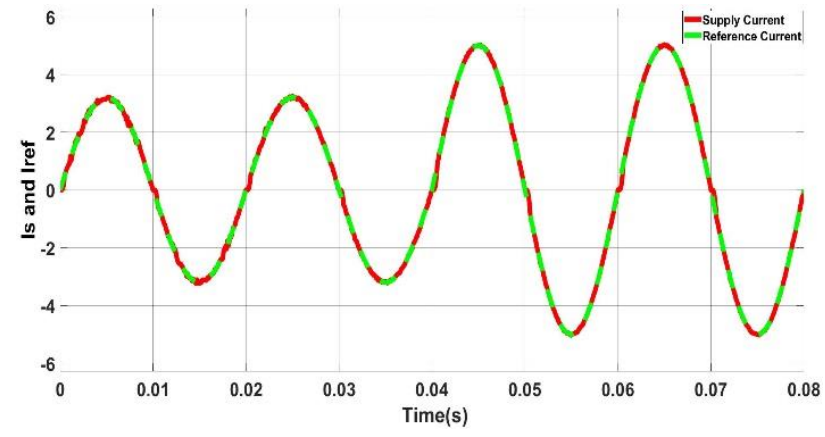

Figure 9. The step response signal with Iref $=3.2 \mathrm{~A}$ at $0.04 \mathrm{~s}$ and Iref $=5 \mathrm{~A}$ at $0.08 \mathrm{~s}$

\section{CONCLUSION}

This paper has been presented the simulation results for the proposed APF with HCC method. The used of HCC can reduce the switching losses in sinusoidal supply current signal and reduce the THD level to comply with IEEE 519 standard, thus, solve the power quality problems. For future recommendations, it is highly recommended to apply the Hysteresis Current Control techniques in domestic applications and industrial sectors such as three-phase induction motors. The use of such method in three-phase induction motors can solve the distorted supply current waveform due to the non-linear torque, flux and current regulation.

\section{ACKNOWLEDGEMENTS}

Authors gratefully acknowledge the financial support from Ministries of Higher Education Malaysia and Research Management Centre (RMC) Universiti Teknologi MARA Grant No: 600-RMC/DANA 5/3(TD) BESTARI (001/2019).

\section{REFERENCES}

[1] R. Baharom, M. K. M. Salleh, and N. F. A. Rahman, "Active power filter with direct output voltage control of single-phase AC to DC converter," PECON 2016 - 2016 IEEE 6th Int. Conf. Power Energy, Conf. Proceeding, no. Ccl, pp. 412-416, 2017.

[2] A. S. A. Hasim and M. K. Hamzah, "Single-phase shunt active power filter using boost rectifier technique," Proc. IEEE Int. Electr. Mach. Drives Conf. IEMDC 2007, vol. 2, pp. 1294-1299, 2007.

[3] A. S. A. Hasim and M. F. Saidon, "Development of a single-phase shunt active power filter using boost rectifier technique," SCOReD 2006 - Proc. 2006 4th Student Conf. Res. Dev. "Towards Enhancing Res. Excell. Reg., no. SCOReD, pp. 262-265, 2006.

[4] V. Kavitha and K. Subramanian, "Investigation of power quality issues and its solution for distributed power system," Proc. IEEE Int. Conf. Circuit, Power Comput. Technol. ICCPCT 2017, 2017.

[5] B. Badrzadeh and M. Gupta, "Practical experiences and mitigation methods of harmonics in wind power plants," IEEE Trans. Ind. Appl., vol. 49, no. 5, pp. 2279-2289, 2013.

[6] A. Kumar, D. Chatterjee, and A. Dasgupta, "Harmonic mitigation of cascaded multilevel inverter with non equal DC sources using hybrid newton raphson method," 2017 4th Int. Conf. Power, Control Embed. Syst. ICPCES 2017, pp. 1-5, 2017. 
[7] N. Kim, H. Jafarian, B. Parkhideh, and J. Enslin, "Performance and mitigation strategy of distributed AC-stacked PV inverter architecture under grid background harmonics," 2017 IEEE Energy Convers. Congr. Expo. ECCE 2017, pp. 2291-2295, 2017.

[8] Y. Xu, X. Xiao, H. Liu, and H. Wang, "Parallel operation of hybrid active power filter with passive power filter or capacitors," Proc. IEEE Power Eng. Soc. Transm. Distrib. Conf., vol. 2005, pp. 1-6, 2005.

[9] K. Amei, A. Kumagai, T. Ohji, K. Kiyota, and M. Sakui, "Characteristics of new single phase voltage doubler rectifier circuit using the partial switching strategy," Proc. Int. Conf. Power Electron. Drive Syst., pp. 1107-1111, 2018.

[10] H. Vahedi, A. Sheikholeslami, and M. T. Bina, "Reverse direction of hysteresis bandwidth calculation to fix the switching frequency employed in active power filter," World Appl. Sci. J., vol. 15, no. 7, pp. 1007-1011, 2011.

[11] A. Awasthi and D. Patel, "Implementation of adaptive hysteresis current control technique for shunt active power conditioner and its comparison with conventional hysteresis current control technique," 2017 IEEE Int. Conf. Signal Process. Informatics, Commun. Energy Syst. SPICES 2017, pp. 4-9, 2017.

[12] A. Idris, R. Baharom, N. R. Hamzah, and M. K. Hamzah, "Hysteresis current control for AC-DC converter using single-phase matrix converter fed permanent magnet motor," ISCAIE 2014 - 2014 IEEE Symp. Comput. Appl. Ind. Electron, pp. 117-120, 2015.

[13] A. Idris, R. Baharom, N. R. Hamzah, M. K. Hamzah, and M. K. Mohd Salleh, "Studies on performance of Proportional Integral and Hysteresis Control in Current Control Loop for AC-DC converter using SPMC fed PMDC motor," Conf. Proceeding-2014 IEEE Int. Conf. Power Energy, PECon 2014, pp. 354-359, 2014.

[14] H. Mao, X. Yang, Z. Chen, and Z. Wang, "A hysteresis current controller for single-phase three-level voltage source inverters,” IEEE Trans. Power Electron., vol. 27, no. 7, pp. 3330-3339, 2012.

[15] Y. Ounejjar, K. Al-Haddad, and L. A. Dessaint, "A novel six-band hysteresis control for the packed U cells sevenlevel converter: Experimental validation," IEEE Trans. Ind. Electron., vol. 59, no. 10, pp. 3808-3816, 2012.

[16] S. Gautam and R. Gupta, "Unified time-domain formulation of switching frequency for hysteresis current controlled AC/DC and DC/AC grid connected converters," IET Power Electron., vol. 6, no. 4, pp. 683-692, 2013.

[17] Z. Yao and L. Xiao, "Two-switch dual-buck grid-connected inverter with hysteresis current control," IEEE Trans. Power Electron., vol. 27, no. 7, pp. 3310-3318, 2012.

[18] C. Attaianese, M. Di Monaco, and G. Tomasso, "High performance digital hysteresis control for single source cascaded inverters," IEEE Trans. Ind. Informatics, vol. 9, no. 2, pp. 620-629, 2013.

[19] F. Wu, B. Sun, K. Zhao, and L. Sun, "Analysis and solution of current zero-crossing distortion with unipolar hysteresis current control in grid-connected inverter," IEEE Trans. Ind. Electron., vol. 60, no. 10, pp. 4450-4457, 2013.

[20] H. Maamri, I. Bahri, and N. Derbel, "Adaptive hysteresis controller for the Switched Reluctance Machines," 2014 Int. Conf. Electr. Sci. Technol. Maghreb, Cist. 2014, no. 5, pp. 14-19, 2014.

[21] H. Komurcugil and O. Kukrer, "A double-band hysteresis control approach for three-phase four-switch active filters with switching frequency mitigation,” IECON Proc. Industrial Electron. Conf., pp. 1021-1027, 2014.

[22] R. Blundell, L. Kupka, and S. Spiteri, "AC-DC converter with unity power factor and minimum harmonic content of line current: Design considerations," IEE Proc. Electr. Power Appl., vol. 145, no. 6, pp. 553-558, 1998.

[23] Y. Choi, N. Cho, W. Kwon, and D. Lee, "Switching frequency limiter 2.1," 13th Int. Conf. Control. Autom. Syst., pp. 431-433, 2013.

[24] D. C. Bhonsle and R. B. Kelkar, "Design and simulation of single phase shunt active power filter using MATLAB," in 2011 International Conference on Recent Advancements in Electrical, Electronics and Control Engineering, pp. 237-241, 2011.

[25] A. Karaarslan, "Hysterisis control of power factor correction with a new approach of sampling technique," IEEE Conv. Electr. Electron. Eng. Isr. Proc., pp. 765-769, 2008.

[26] A. Idris, R. Baharom, N. R. Hamzah, and M. K. Hamzah, "Controlled AC-DC converter fed permanent magnet DC motor using single-phase matrix converter," ISBEIA 2012 - IEEE Symp. Business, Eng. Ind. Appl., pp. 7-12, 2012. 